\title{
The Breton Language Autobiography of Julien Godest (i905-i3): Current Events and Cultural Archaism on the Eve of the $20^{\mathrm{TH}}$ Century
}

\author{
Nelly Blanchard
}

\section{Introduction}

Julien Godest (1849-1933) was a farmer from Chapelle-Neuve and Callac in the Côtes-d'Armor (north-western Brittany). Unlike most of his fellow agricultural labourers, he was literate and, at some point between 1905-13, he wrote a 300-page autobiography in Breton. ${ }^{1}$ He had been solicited to undertake this task by François Jaffrennou (1879-1956), one of the key leaders of the Emsao movement. ${ }^{2}$ Godest began this long literary work to testify and to reflect upon his experiences and those of his brother during a crucial period of social, political, geographical, cultural and linguistic change at the end of the $19^{\text {th }}$ century, a period that ushered in what historians define as the "modern age".

Rather than assume the existence of clearly defined cultural entities - for example, Breton or Celtic on the one hand and French on the other - the question of cultural and linguistic contacts raised by the theme of this colloquium induced me to read the text and analyse it in a way that is similar to the manner in which the author himself seems to have perceived his own identity, that is, via cultural change and other recurring events that punctuate his autobiography. In order to provide elements of a response, I shall concentrate on his experiences in the face of social and cultural change, in order to understand what he seems to perceive as fundamentally significant in his own culture. I shall then attempt to shed some light on the nature of this literary text. Finally, and perhaps paradoxically, I shall examine its value as a tool of cultural archaeology.

1. His manuscript is kept at the Archives Départementales du Finistère (fonds Taldir-Jaffrennou) and has recently been published (Blanchard 2020). I would like to thank Gary Manchec-German who translated this article into English and also provided translation of the relevant passages.

2. Emsao ('Rise Up') was a Breton patriotic movement founded in 1898 (Union Régionaliste Bretonne, with a bardic college, etc.). On the history of the Breton movement, cf. Nicholas (1982) and Deniel (1976). 


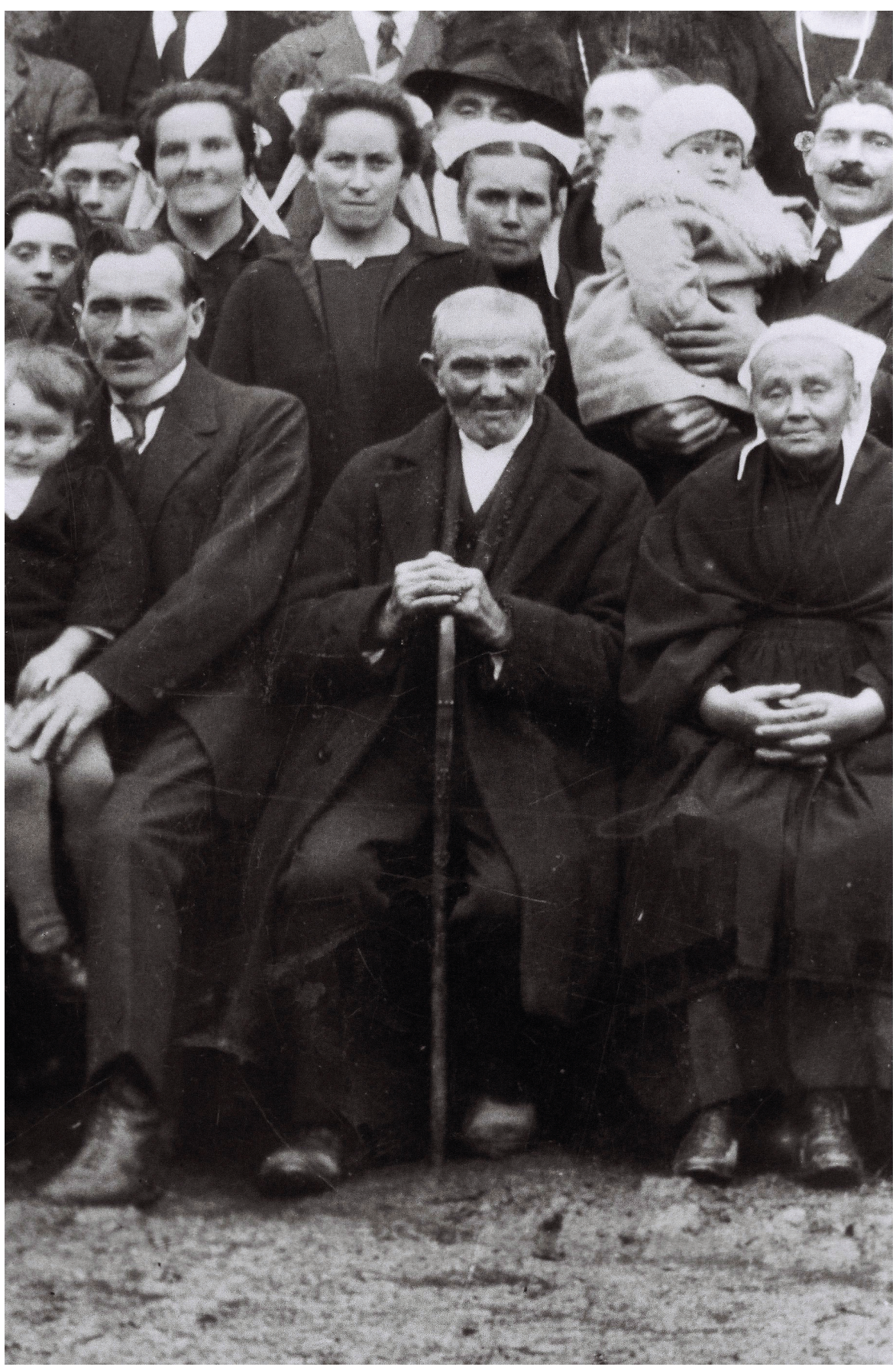

$(\varphi$

Figure 1. Portrait of Julien Godest (private archive). 


\subsection{Coping with modernity: Change and permanence}

Godest's text offers the reader several angles of observation with regard to the manner in which human beings cope with change. In his account, he describes his brother's experiences in the French Army while doing his compulsory military service. During this time, he recounts how this monolingual Breton learnt French, and his involvement in the fighting during the Commune de Paris. ${ }^{3}$ The book also reveals the author's opinions about two phenomena that gain in importance towards the end of the $19^{\text {th }}$ century: the exodus of Bretons to the big cities, most notably towards Paris, and the dechristianisation of France.

\subsection{Coping with cultural change}

Julien Godest explains how his brother, Jean-François Godest, coped with the radical social, linguistic and geographical transformations from being a farmer in western Brittany to becoming a soldier in the French Army for five long years of his life. ${ }^{4}$ Jean-François left his native Chapelle-Neuve in 1866 and was successively deployed to Clermont-Ferrand, Vienne, Abou-Saada in Algeria and, finally, to Paris in 1871. Far from his monolingual Breton-speaking family, he was obliged to live with soldiers whose daily language was French, a context in which he was forced to adapt to radically new sociocultural realities.

What the author highlights in this experience of transformation - from a Breton farmer to a French-speaking soldier of France - is that it was only a temporary experience, and had only a superficial impact on his brother's character and values. On the other hand, the relative ease with which his brother learned to adapt to these new situations merited that his experiences be described as a model for others to follow.

Godest writes that when his brother first arrived at the army barracks, he did not understand a single word that the other soldiers were saying to him, and when he began singing them a song in Breton, he slipped a coin to each of his two sergeants, offering to pay a round for everyone in the room and, in that way, he was rapidly integrated in the unit: the brigadier, who appreciated the gesture told Godest, "Thank you, lad, you've earned the right to my protection". ${ }^{5}$

3. This was a turbulent insurrectional period in May 1871 during which a part of the population, seduced by republican democratic ideals, confronted the Assemblée national, which was composed mainly of monarchists who sought to undo the effects of the French Revolution.

4. Their military service had been reduced from seven to five years as a result of the problems encountered by the conscripts who had been forced to put down the rebellion known as the "Commune". Julien did not do his military service and does not explain why. He only refers to a short period during which he served in the Garde mobile in Guingamp. Nevertheless, this was not comparable to his brother's experience in the French Army.

5 "Ar mest stad ennan gant kemense, a lavaras da c'hodest (mercie mon garçon, vous méritez ma protection.) (Trugare dac'h ma fot, c'houi a verit bean zikouret ganin.)" (Blanchard 2020: 160-1). 
Pa oa eta godest en he gamp a zoudard evit an noz kentan, oll zoudardet he gamp en nem vodas endro dean evel eun tol gwenan, peb hini a lare pe a lavare dean he jonj, mes godest na entente netra, godest a gomze deze ive d'he dro, mes c' he na ententent ket keneubeut, ha sethu godest o tont eur jonj en he ben, riman eun tam kanaouen neve da ganan deze, ... ar zoudardet na defoa ententet netra er ganaouen, mes an ton ken brav ha ken sklentin, moéz godest, ken brav ak eun ogrou, an aèr a nean ken joaûs, an oll dreou ze, a reas kement a blijadur dar zoudardet ma tansent gant ar blijadur, pa oa fin dar c'houblet, a oa straket dean an daouarn, en neur lavaret bravo breton, neuze godest a reas eur zel endro dean ak a velas dao, ak a defa doare da vean mestrou, ha na nem dromple ket, rak eunan a oa marichal de logi, ak egile a oa brigadier, godest eta en neur rei ar c'hrok dorn (poignet main) dan daou man, a lakeas en dorn peb hini aneze, eur pes dek gwennek, na oa ket kals a dra, mes bepret a tiskoue bolonte vad.

(Blanchard 2020: 158-61)

When Godest spent the first night in the barracks, all the soldiers gathered round him like a swarm of bees, each one saying a word to him. But Godest didn't understand a thing. Godest spoke to them in return but they didn't understand anything either. So, it's at that moment that an idea popped into his mind: why not sing them a song? ... The soldiers didn't understand the words in the song either, but the tune was so beautiful, cheerful and crystal clear (Godest had a voice as beautiful as an organ), that this gave the soldiers great pleasure and they began dancing with joy. At the end of the couplet, they applauded him saying "Bravo Breton!" Godest took a quick look around him and noticed two men who looked like they might be NCOs. He was not wrong, one being the maréchal des Logis and the other the brigadier. While shaking their hand (one handshake), Godest slipped a 10 sous coin to each of them. It wasn't much but it was a sign of his goodwill.

Then came the time for him to learn to speak and read French as well as to study arithmetic, all at the same time. At the end of the first six months of training, Godest had come to speak French relatively well. "I don't say he spoke it like a scholar, but he spoke it correctly enough for the things he needed" ("A ben ar c'hoec'h mis ze, Godest a gomze mad ar gallak, na lavaran ket a oa eun doktor, mes koms mad a rae en kement ma nefoa ezom en peb tra." Blanchard 2020: 180-1). As far as his military prowess is concerned, within a mere six months he had mastered every skill he had been taught. He even counted among the rare soldiers who could execute certain feats such as the saut supérieur, which consisted in leaping over three horses while doing a somersault! Finally, in the context of his military service, which was viewed as only a temporary period in his life, his adaptation to the new cultural conditions are valorised by the author, but these experiences are not considered to have had a profound impact on his fundamental cultural values. 


\subsection{Coping with fundamental social changes}

Godest sought to accord a place of importance in his text that would be dedicated to the context in which the lives of those he discusses evolved. Consequently, the author points out the rural exodus of Bretons from western Brittany to the big cities and the dechristianisation of society. He believes the demise of Catholic Christianity is the result of this geographical and cultural uprooting.

Contrary to his brother's successful integration in the army, these two great social changes are the object of limitless criticisms and fierce resistance on the part of the author. For example, he highlights in great detail the moral catastrophe that the exodus had had on the Bretons of western Brittany; in particular, Godest evokes the tragic destiny of Breton women.

Ar pes a lavaran aman deus ar botret, a lavaran ive deus ar merc'het a ia ermaes ho bro, kals tristoc'h c'hoas eo doare kals a neze, ken na gredan ket ho c'henvel gant aon da rei ar skouer fal, gant aon da rei annoudeges da eunan benak deus bueo, ken c'hudur darn aneze, méz peb bro int zur mad en wirione, ha c'hoas a verreont ho bue ouspen deus anter darn a neze, ha c'hoas eûrus mar na vent ket daonet.

(Blanchard 2020: 148-9)

What I have just said about men is also true for women who leave their country. For most of them, their situation is even sadder. I dare not even describe it for fear of setting a bad example, for fear of revealing to anyone the depraved lives which some of them lead. They are the shame of every country, and, to tell the truth, some of them shorten their lifespans by half. They'll be lucky if they are not damned afterwards.

His firm condemnation of those who leave western Brittany and abandon their religion is a testimony to the beliefs that are at the core of Godest's character. This is not a superficial change for him; rather, it is at the very heart of what he considers to be his cultural identity. For him, renouncing it is an intolerable act that goes against nature and God's will.

\subsection{Coping with political innovations}

Finally, in the face of these ideological changes, Julien Godest does not adopt a clear political position. His moral code forces him to relegate political questions to the back burner, explaining the latter as contingent, accidental and having no real hold on his Breton cultural foundations. Jean-François' experiences in the 1871 Paris insurrection of the Commune are a prime example of this and he never commits himself to defending the political positions of one camp or the other. Rather, the only concern in his mind is to do his duty as honestly as possible. Put another 
way, this means being a good Christian and a good soldier. It is for this reason that he actively participates in the repression of the anti-monarchist Commune rebels.

Godest eta a nefoa gret brezel en deze, ha labouret evel eun tigr konnaret, evit difen lezen ar gouarnamant deus a behini a oa hen ar zoudard, lavaret a rae dezan he c'heunan ar c'homjou man, evit jerviji mad ar gouarnamant ec'hon deut dan armee, oas dan nep a nem zavo en he enep, pa eo gwir n'eo ket enep doue a nem zav ar gouarnamant, rak mar vije, a mije lavaret nan, rak ret eo zenti kentoc'h eus doue, evit eus ar gouarnamant, mes pa eo evit derc'hel peb eurs vad, ha c'hars ar revolt a labour ar gouarnamant, me en difenno zur mad, en keit a ma vo eur banac'h goad ebars em gwaziou, breizat a c'hon ha breizat a vin, ha keit a ma vo em gwaziou eur strill goad, me vo bepret gwir vreizat.

(Blanchard 2020: 264-5)

Godest had thus made war that day and he had fought like an enraged lion to defend the law of the government he served. He spoke to himself in the following words: I joined the army to serve the government. Woe be to him who should revolt against it! In fact, it is not against God that the government is fighting because, in that case, I would have refused; one had better obey God than the government. But because the government is engaged in maintaining order and stopping the insurrection, I will defend it without hesitation until the last drop of my blood has been shed. I am a Breton and I'll remain so. As long as blood flows in my veins, I'll remain a true Breton.

It is this same political non-engagement that leads him to adopt certain arguments advanced in the regionalist ideology of Emsao, ${ }^{6}$ such as their condemnation of the rural exodus as well as the abandoning of the Breton language and the Catholic religion. These are all arguments that François Jaffrennou had certainly impressed upon him. Yet, at the same time, he does not overtly support patriotic Breton political ideas at any point in his book.

Taking into consideration the totality of Julien Godest's multifaceted cultural portrayals of what one might interpret to be cultural contacts, or at least, experiences of change, it is possible to distinguish what, for him, is representative of a permanent Breton identity. It is these fundamental criteria that must be preserved at all costs. Godest interprets those changes, which provoke only a temporary disruption of that identity, to be an enrichment and even a manner of testing and verifying the solidity of his culture in the face of possible acculturation to French urban society.

6. Breton patriotic ideology was based on the unique role of every region in the French State and the development of inter-Celtic bonds, with the aim of reviving Brittany's Celtic past, and also on a form of neo-paternalistic rural ideology. 
What Godest judges to be his culture and that of western Brittany is in fact the Catholic religion and, by extension, its bonds to Brittany and the Breton language. These are two corollaries that are perceived by the author as being part of the divine order, and thus a representation of the permanent nature of religion.

Leaving Brittany, as long as it is for a transient period, as in the case of doing one's military service, has no negative impact on the culture of western Brittany. On the other hand, leaving Brittany for good, and even worse, settling in a city, raises the spectre of acculturation. In the same way, learning and mastering the French language in order to do one's duty as a soldier is praiseworthy, but renouncing the Breton language would be an offence to God! Indeed, according to the author, the Breton language was nothing less than the original language of heaven! Likewise, living in other places and participating in important political events do not, in and of themselves, result in acculturation, as long at the thread of religious fidelity has not been broken.

\subsection{A culture of submission and resignation}

\subsection{Three forms of submission: to the Catholic church, the established social order and to the French Republic}

Julien Godest did not write a treatise or an ethnographic text on the culture of western Brittany. His purpose was to record his envorennou, memories and those of his brother. The analysis of the recital of their experiences in various cultural, social and political contexts demonstrates that the author had a patently hierarchical view of his culture, and in his writing one can see that it is founded on three levels of submission.

The form of submission that is most obviously asserted and omnipresent throughout the text is Christian submission to the divine order. Enhancing specific episodes of Jean-Jacques' life relieves him of having to adopt any political engagement, thus sparing him from his sense of guilt ("it is God who has me do these things, not me"). It is this logic that dominates all others when he must make potentially difficult moral decisions.

A second form of submission, which may be even older, is also present in his text: submission to his superiors. One senses this is an inheritance from feudal times and, in social terms, it becomes apparent in the way he interacts with those who are above him socially. It is also a Catholic heritage, which invites believers to remain in their social group and accept their plight as well as they can. Julien

7. These ideas were diffused most notably by Father Pezron (1703). Cf. Joseph Rio's study on Celtomania (Rio 2000). 
Godest is obsessed with hierarchy and the respect for social order, particularly while he is in the army. But this is especially visible when he is invited for lunch by the Justice of the Peace in Callac, near his home in Côtes-d'Armor. He fears that, by accepting the invitation, he will be rising above his station and will thus commit the "sin of pride".

The final form of submission is to the French Republic. The Third Republic was a governing institution that had already been in power for 40 years when Godest wrote his book. Yet, the democratic values it purported to defend seem to have had little or no effect on him in terms of his political emancipation. ${ }^{8}$ This text is a testimony to the longevity of this culture of obedience and submission to hierarchy in popular Breton society, a view that was perceived to be part of the natural or divine order.

\subsection{A hagio-autobiography}

As we have already stated, Julien Godest's literary project was based on his own life and that of his brother. Both accounts are very similar because they follow a single line of conduct: that of resignation, unconditional respect for God's will and the struggle to maintain the permanence of divine order. In an effort to define their lives, the author uses the term tragedien, on the model of the sacred Christian tragedies and with the meaning of "an exemplary life of a saintly person". Indeed, the objective of Godest's book was to illustrate the praiseworthy nature of his and his brother's lives and their devotion to God's will. Godest's bio-autobiography reviews all the heroic deeds of the two principal characters, the goal being to illustrate their inflexible obedience in matters of religion. This approach tends to present the two as saintly characters, thus rendering the text a variety of hagio-autobiography.

If the two characters are not explicitly presented as "saints" per se, they are depicted as exemplary people, models for other Bretons to follow. This dual account of their lives is thus not oriented towards the past but rather towards the present and future. The message of the text is intended to remind Breton readers not to stray from the path of righteousness by avoiding the dangers of acculturation. In this way, they will remain faithful to their country, their language and, especially, their Catholic religion. This simultaneously implies advocating and encouraging actions in support of the benefits of a well-regulated life while simultaneously condemning the evil actions of those seeking to foment social dissent and disorder.

One of his constant concerns is the link between faith and life, in other words, relating their experiences and those of their potential readers in a way that will be relevant to the events of their day. Here, his concerns are more contextual than

8. One wonders how long it took for the democratic values of emancipation advocated by the French Republic to filter down to the population at large in western Brittany and in other regions of France. 
conceptual. The author uses a tone and a style that recall a form of homiletic discourse. The text is thus composed of an ensemble of thematic axes that highlight the permanence of the choices made by characters relative to what they consider to be the proper respect of Christian morality. Each thematic component is formed by the combination of concrete examples (parts of a person's life story) that illustrate a dimension of Catholic doctrine (and potentially arguments and explanations regarding its origins).

To accomplish this, Julien Godest adopts several methods:

(1) The use of the oral "Question-Answer" model used in the Catechism;

(2) The utilisation of sociolinguistic vignettes, which permit him to paint the portraits of certain individuals who trouble the established divine order (e.g. the archetypical coarse soldier or the condescending, atheist Colonel...);

(3) Encouraging moral conduct through a series of moral imperatives;

(4) The imaginary construction of order, the coherence of moral behaviour and encouraging continuity with respect to modernity, which decomposes the fundamental basis of society;

(5) The imaginary construction of a line of descent: the lineage of the divinely-elected Breton people, the linguistic lineage of Breton as the mother language of humanity;

(6) The invitation to humility by the permanent and obsessive reality of the hierarchy of values and duties: "God first, followed by Jesus, the Virgin Mary and the saints and angels... followed by Godest himself."

\section{An archaic literary vestige}

What are the Envorennou ar barz Juluan Godest ('The memories of Julien Godest the Bard')? Is it a favourite genre of the labouring classes? In fact, the life story or autobiography of unusual and marginal authors such as Godest do not resemble in all respects the standards set by autobiographies described and analysed by Philippe Le Jeune (1996) or those presented in the adventures of Jean Conan (1990), written in alexandrine verse, or the life of Hervé Burel (Blanchard 2011), which is a hybrid form of pamphlet-autobiography. Julien Godest's life story could be described as a hagio-autobiography. If this characterisation is accurate, how can this genre be defined? 


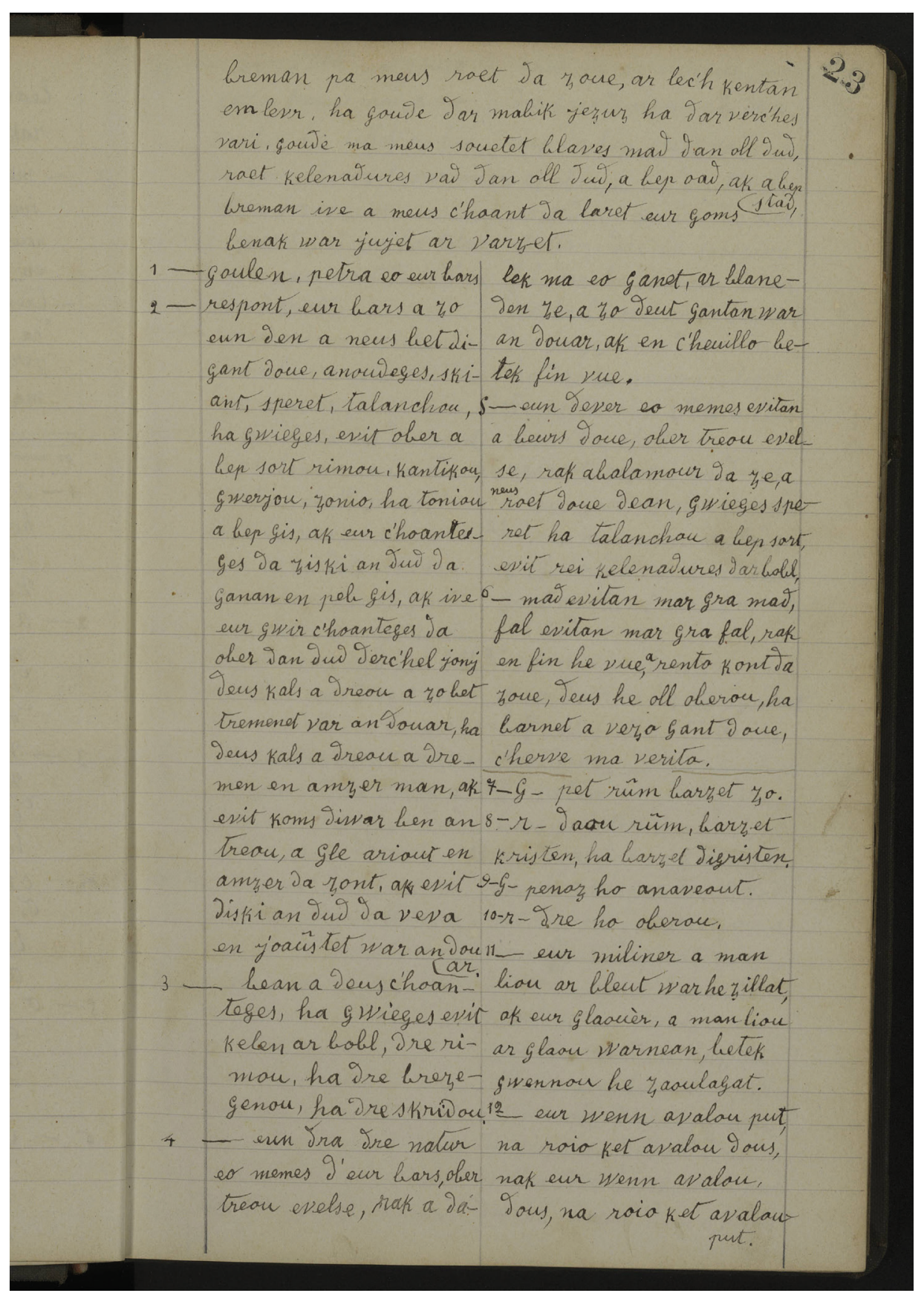

Figure 2. Example of a page from Julien Godest's manuscript, based on the "Question-Answer" model of the Catechism 


\subsection{An ultra-marginal literary work}

Godest's text reflects the characteristics of Breton popular culture and, as such, is located on the extreme fringe of the literary scene. The homiletic discourse that influences it is designed as a moral guide for his compatriots. It is based on the idea of conversational and oral exchanges and is thus the reflection of a culture that is, more or less, shared. What is surprising, however, is to observe the emergence of a piece of literature penned by a farmer who is, to all intents and purposes, a Breton monolingual. Linguistically and socially, Godest is situated on the periphery of the literary scene of his time. Even though he had learnt to write through the medium of French, he could not master French well enough to write his book in French. In this regard, he belongs to a small fringe of the population of western Brittany that was trapped between two types of acculturation. The first involved the mastering of writing, and the second dealt with mastering the French language in a diglossic framework in which Breton was clearly viewed as the inferior language in society at large. It is only in such a context that such a text could have been produced. ${ }^{9}$

Even if one cannot deny the singular nature of Godest's personality, his text sheds light on popular cultural features that were undoubtedly largely shared during his lifetime. The contradiction between what is marginal and shared culture reveals the persistence of older cultural codes, which make this an "extra-ordinary" text in the literal sense. In this way, it can serve as a tool for cultural archaeology.

\subsection{A tool for cultural archaeology}

Indeed, if peripheral literatures are sometimes characterised by writings that are the consequence of a cultural lag or attempts to replicate the literature of the dominant culture, Godest's text offers the advantage of granting the reader access to an ancient form of Breton religious culture that seems to have developed on the margins of the Counter-Reformation (Blanchard 2013). ${ }^{10}$ It is not especially the Catholic writings of his day that seem to inspire him. For instance, the Lizero Breuriez ar Fe ('Letters of the Fraternity of Faith') deal essentially with Catholic evangelical missions. ${ }^{11}$ Other periodicals inspired by the Catholic Church, such as Feiz ha Breiz ('Faith and Brittany'),

9. The writings of Emsao militants in favour of the diffusion of the Breton language does not enter into this framework because these are viewed as acts against diglossia.

10. The Counter Reformation in $17^{\text {th }}$ century western Brittany was conducted by the Jesuits to achieve what they called a second conversion of the Breton-speaking masses, and was accompanied by a structured, systematic religious training. This was organised and instituted by the priests and their Jesuit Colleges. Additional tools were imagined and employed to achieve this task: written texts, oral texts in the form of canticles, the sculpting of statues and stained classes, etc., all having the objective of conveying biblical messages.

11. These missions, in which many Breton priests participated, occurred in various areas of the French Empire in Asia, America, Africa and elsewhere. 
Kroaz ar Vretoned ('Cross of the Bretons') and Dihunamb ('Let us Wake Up'), do not have the same tone or homiletic form as Godest's text, even if one finds a certain number of common arguments. Journals, such as Taldir-Jaffrennou's An Oaled ('The Hearth') or Ar Vro ('The Country'), published only a few rare extracts of Godest's works, and even these were reworked. The editors certainly judged that Godest's book did not reflect, or at least no longer reflected, the thinking of the Catholic bourgeoisie, which composed the principle readership of Emsao. ${ }^{12}$

The homiletic project exposed in Godest's hagio-autobiography undoubtedly reflects one of the oldest strata that can be identified in the author's religious ethos, in which one distinguishes the tone and style of texts associated with the preaching style that was common during the Counter-Reformation in the $17^{\text {th }}$ century, with an almost total absence of references to the Church and priests. ${ }^{13}$ This strain of religious belief is also expressed in the form of songs that were put to well-known tunes, ethnocentric theories about the origins of the Breton language, arguments presented by Emsao, etc., as well as helpful medical formulas. Nevertheless, these strata all seem to be unified by the homiletic type of discourse that is the principal characteristic of the text.

\subsection{Conclusion}

The result is that, beyond the experiences regarding their entry into modernity, which makes the text an eyewitness account of the last decades of $19^{\text {th }}$ century Breton society, Godest's book provides exceptional insight into an archaic form of Breton culture that was profoundly bound to religion and, in particular, a form of religious culture intimately associated with the Catholic Counter-Reformation, a culture that seems to have taken root in Brittany and developed with particular vigour in the Breton-speaking regions of the country.

\section{University of Western Brittany (Brest)}

12. Blanchard (2014). This perceptible tension resulting from this quasi-absence of the publication of Godest's book allows us to better apprehend Emsao's ideology, namely, the cleavage between the popular culture they claimed to defend and the popular belief system of that culture which it did not particularly advocate (cf. also the literary texts in Breton that remained unedited for a long time, such as those of Kerneveyer, Conan, Burel Laouenan and others).

13. In the first 150 pages, there are only two references to the Church and four occurrences of the word "priest". I can only propose a few hypotheses to explain this absence. I believe that the Counter-Reformation had to confront the powerful Protestant conception and significance of "inner faith" as opposed to the superficial religious rites and rituals. Paradoxically, this was expressed by insisting on the development of a more intimate and personal homiletic exchanges with God, which was so typical of Protestantism. This was probably expressed in sermons during his youth, and traces of this remained in Godest's oral culture. But, again, this is only a hypothesis. 


\section{References}

Blanchard, N., ed. and trans., 2011, Histor eur famill eus Breï-izel. Histoire d'une famille de Basse-Bretagne, manuscrit d'Hervé Burel; établi, traduit et présenté par Nelly Blanchard, Morlaix, Brest: Skol-Vreizh, CRBC.

Blanchard, N., 2013, 'Temporalité de la circulation des modèles dans la littérature de langue Bretonne: les cas Conan, Burel, Godest'. Lecture presented at Temporalidades de los intercambios y de la apropiación cultural, UNAM, Mexico (May 2013).

Blanchard, N., 2014, 'Julien Godest, paysan autobiographe sous l'aile de TaldirJaffrennou', La Bretagne Linguistique 18, 7-31.

Blanchard, N., ed. and trans., 2020, Envorennou ar barz Juluen Godest. Souvenirs du barde Julien Godest, Brest: CRBC.

Conan, J., 1990, Les Aventures du Citoyen Jean Conan. Avanturio ar citoien Jean Conan, Morlaix: Skol Vreizh.

Deniel, A., 1976, Le mouvement Breton (1919-1945), Paris: Maspero.

Le Jeune, P., 1996, Le pacte autobiographique, Paris: Seuil (1 $1^{\text {st }}$ ed. 1975).

Nicolas, M., 1982, Histoire du mouvement Breton, Paris: Syros.

Pezron, P., 1703, Antiquité de la Nation et de la langue des Celtes, autrement appeléz Gaulois, Paris: P. Marchand.

Rio, J., 2000, Mythes fondateurs de la Bretagne. Aux origines de la celtomanie, Rennes: Ouest-France. 
